\title{
FORCED EMIGRATION AND DESIRED RETURN: THE SOCIAL AND PSYCHOLOGICAL CONSEQUENCES OF THE WARTIME EVACUATION OF GREEKS
}

\author{
EWA NOWICKA
}

\begin{abstract}
Forced emigration and desired return: the social and psychological consequences of the wartime evacuation of Greeks.

The subject of this article is the fate of the Greek political refugees - specifically persons forcibly resettled in Poland and other countries of the Soviet Bloc, evacuated from territories engrossed in the Civil War of 19461949. After a long period in exile, some returned to their home country and began a new life, struggling with economic, familial, social, linguistic and cultural problems. The history of the Greek refugees and their re-immigration illustrates the irreversibility and irreparability of the social and psychological damage done by forced migration. Returns to the homeland did not reinstate balance, and did not ease the dilemmas initiated by the first resettlement. History is stuck in the memories as well as the everyday lives of the return migrants and their social milieus; this creates divides, mutual strangeness, and social tensions. Compulsory movement of populations - leading to the severance of connections with one's fatherland, hometown, mother tongue, and home culture - causes subsequent conflicts and identity problems which continue to haunt those who returned to their birthplace.
\end{abstract}

STRESZCZENIE. Przymusowa emigracja i oczekiwany powrót: spoteczne i psychologiczne konsekwencje wojennej ewakuacji Greków.

Przedmiotem artykułu są losy greckich uchodźców politycznych, ludzi przymusowo przesiedlonych do Polski i innych krajów obozu komunistycznego, ewakuowani z obszarów objętych wojną domową w latach 19461949. Po długim czasie pobytu na obczyźnie powrócili do rodzinnego kraju i zaczęli nowe życie, borykając się z problemami materialnymi, rodzinnymi, środowiskowymi, językowymi i kulturowymi. Dzieje uchodźstwa i reemigracji Greków ukazują nieodwracalność i nienaprawialność szkód społecznych i psychologicznych wywołanych przez przymusową migrację. Powrót do rodzinnego kraju nie przywraca równowagi, nie łagodzi problemów, które rozpoczęło pierwotne przesiedlenie. Historia tkwi w pamięci i codzienności migrantów powrotnych i ich otoczenia, tworząc podziały, wzajemną obcość i napięcia społeczne. siłowe przeniesienia ludności, prowadzące do zerwania relacji z ojczyzną, miejscem rodzinnym, kulturą rodzinnego kraju, powodują kolejne konflikty i problemy tożsamościowe, dręczące tych, którzy powrócili do miejsca pochodzenia.

Author: Ewa Nowicka, Collegium Civitas, Institute of Sociology, Defilad square 1, 00-901 Warsaw, Poland, ewanowickarusek@gmail.com

Keywords: forced migration, return migration, Greek refugees, Greek Civil War, re-adaptation

Balcanica Posnaniensia. Acta et studia, XXIV, Poznań 2017, Wydawnictwo Instytutu Historii UAM, pp. 83-100, ISBN 978-83-65663-50-4, ISSN 0239-4278. English text with summaries in English and Polish.

doi.org/10.14746/bp.2017.24.6 


\section{INTRODUCTION}

This article is dedicated to the Greek political refugees - persons resettled and evacuated between 1946-1949 from regions engrossed by the civil war in Greece - who, after a long absence, returned to their home country to start life anew.

Presented herein will be the results of anthropological fieldwork which I undertook in 2005, conducting in-depth until 2010, yet continuing among Greek repatriates from Poland, Czechoslovakia, and the USSR. This research was of an anthropological nature: the basic research instruments were the interview and observations in the field. In first order I dealt with the territories of northern Greece from which, as a consequence of the Greek Civil War, the largest number of local inhabitants were deported - representing a broad range of ethnicities, including Greeks, Macedonians (Slavs), and Wallachians (Aromanians, Megleno-Romanians). The interviews were also conducted in two metropolitan areas - Athens and Thessaloniki - where the decisive majority of returning migrants settled. To a lesser degree, this project also encompassed the community of Greeks who did not leave Poland.

Among the subjects were the third generation individuals though dominant were those of the older generation. My informants could be segregated into the following categories:

- Representatives of the oldest generation - most often former partisans, persons actively engaged in the civil war, in its events as well as its ideology; in some cases they continue to be active in the Communist Party of Greece;

- Persons who arrived in Poland as adults, yet were not active in the partisan movements, nor were they party ideologues; they have often been politically neutral and unaffiliated with any party;

- Persons who arrived in Poland as children, yet were old enough to be able to preserve clear memories of Greece, i.e., children remembering their homeland environs (heimat, mata ojczyzna) and life in their home village; sometimes they were children of partisans, and sometimes of families not actively involved with the partisans;

- Persons so young at the time of arrival in Poland (or some other Socialist Bloc country) that they could not recall Greece; and

- Persons who were born in Poland (or in Czechoslovakia, Hungary or the USSR), spent their youth in this country, and developed into mature adults there; these individuals decisively belong to the second generation; above all they are children of those who came to Poland at various ages.

The overwhelming majority of the roughly twenty thousand refugees from Greece who arrived on Poland's soil returned to their homeland in the years 19751990; only a small group remained in Poland. It is estimated (by the Towarzystwo Greków w Polsce, TGwP, the Society of Greeks in Poland) that about 1 500-3 000 Greeks live here today. As a reference point, the inhabitants declaring Greek nation- 
ality during the 2002 national census numbered $1,404 .{ }^{1}$ Included in this total, however, would be the Greeks arriving in Poland in later years, not necessarily descended from the families of the refugees.

Changing little since the 1940s, the largest clusters of Greeks in Poland (encompassing roughly one third of the population of Polish Greeks) can be found in Wrocław and Zgorzelec. Today they are still generally to be found in Lower Silesia which had been the primary nucleus of settlement for the Greek refugees, but the remainder is scattered throughout the entire country.

All the rest of this population has departed from Poland (and other asylum countries), although not everyone was able to make their way home. Among them were those who, due to a declared Macedonian nationality, would never be allowed to return to their village of origin if it was within the boundaries of the Greek state. This is associated with a policy still in place in Greece which does not recognize the existence persons of other ethnic or national identities on its territory and among its citizens.

\section{PROBLEMS WITH TERMINOLOGY}

One troublesome doubt which arises is connected with the terms applied to the research subjects under study here: are they refugees, re-immigrants, or repatriates? The terms used are not ideologically or axiologically untainted; each bears certain content and emotional connotations. We are dealing here with a two-stage, bi-level migration. The first stage entailed evacuation from the lands engaged by the civil war to Poland and other Socialist Bloc countries; the second entailed a much belated return to the homeland. Each of these stages is described in various ways.

With reference to the first, we speak of "political refugees" or "displaced persons" or "evacuated persons." With reference to the second, we also use diverse terminology. On the one hand, the term "re-immigrants" or the literal replication of "return migrants" appears to be the most neutral in an axiological sense. On the other, however, "repatriates" evokes some misgivings since they did not find themselves back in their homeland as a result of an organized campaign, but as a consequence of a moderated and mitigated course of politics accompanied by permission for their return on the part of the Greek authorities. ${ }^{2}$

The matter becomes even more complex when we think about migrations, when we consider who can or cannot be labeled a migrant. Migration seems to be a phenomenon which is linked to the dislocation and movement of an individual or group,

${ }^{1}$ GUS, Ludność wedlug deklaracji narodowościowej oraz posiadania obywatelstwa polskiego w 2002 r., http://stat.gov.pl/spisy-powszechne/narodowe-spisy-powszechne/narodowy-spis-powszechny2002/wyniki-narodowego-spisu-powszechnego-2002-narodowosci-oraz-jezyka/ [Access: 06.12.2016].

2 E. Nowicka, Migracje powrotne jako przedmiot badan', "Przegląd Polonijny”, 2007, no 2, p. 75-92; P. Hut, Warunki życia i proces adaptacji repatriantów w Polsce w latach 1992-2002, Warsaw 2002. 
executed consciously and intentionally. The arrival of Greek citizens to Poland and the other Socialist Bloc countries in 1948-1949 was part of an evacuation or displacement - at times it meant the abduction of humans, especially children - and not a conscious or purposeful emigration. Thus the use of the word "migration" itself is highly questionable in such cases.

There is another terminological quandary. A statement that a return migration is a return to the place from which one emigrated is, for a few reasons, inappropriate. "Return migration" cannot signify - as oft-described - a "territorial relocation," metaphorically depicted as a pendulum swinging or a boomerang returning to precisely the same place. Coming back, those who we classify as return migrants do not always land back exactly at the same territorial point of departure. ${ }^{3}$

Moreover, in delineating the spectrum of meanings for "return migration," we assume that such entails simply a movement from one place to the next and then back again to the original place of inhabitance. Life, however, usually turns out to be more complex. Humans resettle in various places, countries, regions, continents, cities, etc., treating each subsequent place as their final place of residence, but sometimes treating migration as a gradual, but constant step-by-step. Hence, in returning, people can likewise choose different places of subsequent residence. Indeed, the Greek return migrants under study here did try to retrace their steps specifically to the locality from which they or their parents had been taken. Often, however, it was impossible to ultimately take up permanent residence there - many, therefore, settled in larger metropolitan areas.

${ }^{3}$ Their return to the home country - like the repatriation of Poles formerly residing in the pre-WWII Eastern borderlands (Kresy), but then coming back from Kazakhstan and other regions of the former USSR - can be treated as a "return migration," albeit not a "pendulum migration" (back to the original starting point) because this was not what happened. Still, in first order, the return migrants are the more or less distant progeny of those who had been settled on Polish territory a long time ago. Secondly, the return is not of a territorial nature, but a cultural, political, and ideological one. Returning individuals do not necessarily end up in the same geographical site, but they end up on territory with which (in some sense) they feel a connection; usually this is a bond established via the group of belonging. The fatherland is the nation's territory, yet not necessarily the place with which we feel the most connected due to personal destiny (see P. Hut, op. cit.; M. Gawęcki, Kazachstańscy Polacy, Warsaw 1996). Similarly, Polish emigrants from France after WWII did not literally come back to the same lands from which they (or their parents) had originated. Instead, they were directed to Lower Silesia (W. Markiewicz, Przeobrażenia świadomości narodowej reemigrantów polskich z Francji, Poznań 1960) - to lands which had not been part of Poland for centuries and with which the Polish society did not identify. Therefore, in the mind's eye of the "returnees," coming home can even entail arrival in a different state but to the very lands from which one emigrated (as a result of national border shifts). We can also speak of a return even if the exact site to which one comes back is elsewhere in the original homeland. 


\section{THE DIASPORIZATION OF GREEKS \\ AFTER THE 1946-1949 CIVIL WAR}

The historical events which led to the outbreak, the duration, and the decline of the 1946-1949 civil war in Greece were highly complex in nature. Among other things, they were connected to a battle for influence on the Balkan peninsula between the USSR and the West. In fact, without the economic and military engagement of these forces outside Greece, the conflict and the war would not have been possible. Taking the above into consideration, certain key and fundamental facts will be presented here. Yet, also keeping the constraints of this article in mind - since its core focus is on issues of social consciousness - I am forced to set numerous aspects aside.

The roots of the history of the Greek Civil War reach back to political and social divisions dating back to previous decades. That said, for the duration of the WWII occupation, a strong partisan movement was operating throughout the country, but roughly divided into a right- and left-wing. The Ethnikon Apeleftherotikon Metopon (EAM, National Liberation Front), a political bloc dominated by communists, arose in the underground; its military organ was the Ethnikos Laikos Apeleftherotikos Stratos (ELAS, Greek National Liberation Army). ${ }^{4}$ A much weaker anti-German and anti-Italian faction of partisans was the right-wing Ethnikos Dimikatikos Elinikos Sindesmos (EDES, Greek Democratic National League) which was led by General Napoleon Zervas. ${ }^{5}$ Between 1943 and 1944, it did happen that ELAS and EDES fought against each other; although numerous accords had been concluded, many clashes occurred. In October 1944 the last German armies retreated from the Greek territory; Bulgaria had already gone over to the Soviet side a month earlier in September. The English were landing in Athens and Thessaloniki, while the partisans were taking over from the Germans in central and northern Greece.

Yet this transition unleashed a new war, this time a civil war between the proand anti-government political fractions. Under the lead of Markos Vafiadis, the EAM/ ELAS forces - now known as the Democratic Army of Greece (DSE) - took advantage of economic and military aid from neighboring communist countries: Yugoslavia, Albania, and Bulgaria. Nonetheless, the American aid provided to the opposing side was much greater. The government armed forces received large amounts of USproduced weapons and equipment. The magnitude of these deliveries was several times greater than the assistance received by the DSE from the communist states. The

${ }^{4}$ R. Clogg, A Concise History of Greece, Cambridge, Cambridge University Press, 1992, p. 149; M. Szymczyszyn, The Greek Civil War (1944-1949) - outline, in: The Polish People's Republic and the Greek Civil War, ed. M. Szymczyszyn, Szczecin, 2016, p. 23-43; N. Marantzidis, The Greek Civil War (1944-1949) and the opening of archives in post-communist Europe, in: The Polish People's Republic and the Greek Civil War, ed. M. Szymczyszyn, Szczecin, 2016; N. Marantzidis: The Greek Civil War (19441949) and the International Communist System, "Journal of Cold War Studies", 2013, no 15(4), p. 2554.

5 R. Clogg, op. cit., p. 151-152. 
official air force completely controlled the skies whereas the communist army (typical of partisan forces) had neither aircraft, nor heavy artillery.

In the face of rising pressures by the government military, the DSE resorted to forced drafting of men and women on the territories it controlled. Furthermore, children began to be transported out from the war-torn areas, beyond the Greek borders. For some (especially the communist side), this was salvation; for others (especially the government side), this was abduction for the purpose of training future fighters for the left wing. It should also be noted that this decision was subject to the interests of the armies and the war. Women relieved from caring for their children could be mobilized for battle; also, fewer persons needed to be fed in the regions where the war was actively being waged. ${ }^{6}$

Additionally, in the course of the civil war, ethnic problems arose and increased in the revolutionary Greek army. For instance, in 1949, about $40 \%$ of all partisans were Slavs, most often describing themselves as Macedonians. In fact, between 1947 and 1949, there were 87 Macedonian-language schools functioning in northern Greece with approximately 10,000 pupils. Two training courses were conducted for teachers and a periodical in Macedonian appeared. ${ }^{7}$ Now this evoked serious disagreements on the left. The Slavic population expected that, upon a communist victory, an independent Macedonian state would be established. This was something which both the left and right perceived as against the Greek raison d'être: it would be treason to relinquish land which had been won with great difficulty. ${ }^{8}$ That said, as a result of the Stalin-Tito conflict, various Greek partisan groups were forced to take a stand.

Meanwhile, in February 1947, the UN Security Council sent an investigative team to verify complaints by the Greek monarchy that neighboring states were assisting partisans and interfering in the affairs of Greece. That commission confirmed the existence of such support, but asserted that it was not in violation of international law. In any case, Yugoslavia ceased to abet the partisan army in 1948, and closed the border to DSE soldiers in 1949. Before it shut in April, however, about 260,000 partisans and their families (including 28,000 children) had already crossed over into Yugoslavian Macedonia and Albania. Subsequently, Stalin preferred to avoid a confrontation with the USA and, thus, after the final break with Yugoslavia, he withdrew from the battle over Greece.

Underscored in accounts is the cruelty and bestiality - heretofore unknown even under German, Bulgarian or Italian occupation - experienced in the course of this civil war. Decapitated heads impaled on poles for public view in Larissa serves as but one example. This kind of ruthlessness was committed by both sides of the conflict

${ }^{6}$ L.M. Danforth, "We Crossed a Lot of Borders". Refugee Children of the Greek Civil War, "Diaspora: A Journal of Transnational Studies", 2003, no 2, p. 169-209; R. van Boeschoten, The impossible return: coping with separation and the reconstruction of memory in the wake of the Civil War, in: After the War was Over: Reconstructing the Family, Nation and State in Greece, 1943-1960, ed. M. Mazower, Princeton 2000, p. 122-141.

${ }^{7}$ I. Stawowy-Kawka, Historia Macedonii, Wrocław 2000.

${ }^{8}$ Stawowy-Kawka, op. cit., p. 272. 
and, in all certainty, spiraled the hatred of the left for the right-wing government and vice versa. ${ }^{9}$

Villages taken over by the communist partisans formed a type of community anchored in both traditional and communist customs. Riki Van Boeschoten points out that Macedonian villages were governed by a rather pragmatic ethos which pragmatism was heightened by wartime reality. For instance, the status of men and women was equalized which was attractive for the latter: their voices were heard, and they were not pushed to the background as village traditions had earlier demanded. Such changes were inspired, on the one hand, by communist ideology and, on the other hand, by practicality in a partisan war situation. Some of the traditional traits of a rural community, so rooted in mutuality and limited acceptance for rule-breaking, were eased by the negative consequences of an armed conflict. Yet another effect was an expanded public sphere. Highly personal affairs, previously addressed within the family, were now publicly debated. Adultery, parental disobedience, familial arguments or the claims of women and wives were taken under consideration during weekly meetings. The communists truly did create communes, but founded on new principles without recognition for traditional ties and obligations. ${ }^{10}$ In many ways the civil war facilitated the disintegration of traditional norms and patterns of behavior.

The Greek Civil War ended, however, with a total defeat of the communist side. On the $24^{\text {th }}$ of August 1949, the main forces of the Democratic Army of Greece, along with the rebel leadership, retreated to Albania. In autumn, the remaining survivors of the partisan units seceded their positions in the mountains - Vitsi on 17 September and Gramos on 28 November. The last partisan troops retreated to Albania. Evacuated to the neighboring countries, and subsequently transported by land or sea, were children who had been removed from their parents as well as adults, be they partisans or evacuated civilians. Many were taken to Soviet Bloc countries or to the USSR itself (more precisely, to Tashkent, Uzbekistan). ${ }^{11}$

It should be stressed that the relocation of Greeks to Poland was not the result of a spontaneous decision undertaken by the Polish communist government but rather an element of a broader Moscow plan. Premier Osóbka-Morawski initially refused to accept Greek children, let alone any refugees from Greece, explaining that Poland was in an exceptionally difficult economic situation after the Second World War and needed to solve the problem of 3 million of its own orphans and homeless. Nevertheless, President Bierut, called for consultation to the Kremlin, did undertake this endeavor. Particularly the western and northern regions (German lands before the war) were made the destination, first for the children and then the adults. The process by which Greek refugees were settled was treated the whole time as a highly confidential operation. In first order, the most heavily wounded were placed in a secret, military hos-

\footnotetext{
${ }^{9}$ R. Clogg, op. cit., p. 171.

${ }^{10}$ R. van Boeschoten, op. cit.

11 L.M. Danforth, op. cit.
} 
pital functioning on the Baltic island of Wolin. ${ }^{12}$ The lesser wounded were routed to other medical centers. Healthy adults were, in turn, directed to settlements near those in which Greek children were residing. Decisions regarding the ultimate destination of children and adults were made by a special committee in Bucharest. Children were separated without consideration for parental or familial ties.

In the case of Poland, the influx of Greek and Macedonian children with or without their families began with the arrival in September-October 1948 of two rail transports by which 1,013 children (513 Greek and 500 Macedonian) came to Poland. Ensuing groups of children (2,092 persons) arrived in April 1949. ${ }^{13}$ Upon arrival, children were separated from any accompanying family and placed in educational institutions and sanatoria, primarily in Lower Silesia. So-called "children's homes" (orphanages) or "educational centers" were established; Polish medical personnel took the children under their wings.

The situation changed in 1949 when the Polish authorities resolved to aggregate all of the refugees in a single place. On 16 September 1949, a vast State Educational Center was established in Zgorzelec, encompassing 14 orphanages, a nursery and preschools, elementary and technical schools, a pedagogical secondary school, as well as a preventorium, hospital, kitchen, and cafeteria. Auxiliary workshops were also established, in addition to a bakery, slaughterhouse, and butchery to produce goods for the Greek community. Here, too, adult "refugees" were also settled. ${ }^{14}$ The first group of adult Greeks came to Zgorzelec on 16 December 1949; the next groups followed in $1950 .{ }^{15}$

\section{WAR AND THE FORMATION OF IDENTITY}

In Poland both the children and the adults felt safe and secure although the memory of the war remained. In conversations with individuals who experienced the war and evacuation, I met with descriptions of scenes in which families were torn apart and scenes of wounds and injuries, disease and death, cruelty and bestiality. Sheer terror emerges in today's responses of the repatriates who share their recollections from their childhood spent during the civil war. They speak of those days with regret, sad-

12 This so-called "Hospital 250" operated on a formerly German, hydroplane base near Dziwnów. The hospital director was Dr. Władysław Barcikowski who is fondly remembered by Greeks to this day.

13 The figures cited are drawn from available sources, but are uncertain. Among those I interviewed were persons who agreed with these statistics as well as those who were inclined to speak of at least twice as high a number of children and adults.

14 The word "refugee" is applied for stylistic reasons, as a form of shorthand with reference to the Greek citizens brought to Poland. They did not - of their own free will on the basis of their own, even spontaneous decision - leave their homeland. These were individuals purposefully taken and transported by external institutions - sometimes feeling no other choice was available, sometimes against their will.

15 M. Wojecki, Uchodźcy polityczni z Grecji w Polsce 1948-1975, Jelenia Góra 1989. 
ness, intensity, but also irony. Descriptions most often used include "macabre," "horrible things," "incredible," "awful," and "terrible."

In the tales of certain people a single chilling event returns over and over - for example, the death of a grandfather whom the closest family was unable to bury. ${ }^{16}$ A 32 year old man, the son of Greek repatriates states straight out: "A vivid tableau is such a thing ... that all the young people want to forget about it, and they forgot, you know, and they forgot." And then he adds, "It was the greatest tragedy in Europe - a tragedy, a tragedy, a real tragedy." Siblings sometimes ended up in different countries; children re-met their parents after many years, sometimes after decades.

From the perspective of the repatriates, the events of the Greek Civil War exist in today's world because those events defined, as a turning point, the meaning of their entire lives. This is how they narrate their lives: the past is a sort of "here and now" phenomenon. After years spent in exile and then back home again, they are aware that they have been defined by the wartime situation - chiefly by the external forces which caused that conflict and played it out without their involvement or against their will. Only a small group of repatriates in Poland managed to create a certain distance from their own situation and a reflexive attitude towards it; primarily well-educated and enjoying numerous contacts with Poles, in their auto-definitions these persons are able to pull away from the civil war, from the political conflict of over half a century ago. Yet this is not a typical situation; it usually pertains to a few individuals, usually born or raised from early childhood in Poland. The oldest of my subjects from among the return migrants - those who were directly engaged in the wartime events - have an image of the conflict as a series of external incidents delineating their fate. In this vision of events, the individual is but a small gear moved by great historical forces.

Noteworthy here is the response of a former partisan who, at the time the interview was conducted was living in Thessaloniki, but had originally hailed from Epirus, from the vicinity of Konitsa. I posed a question regarding the beginnings of the establishment and aims of the organization of which my informant, an old communist and civil war soldier was the leader. The tale takes a surprising turn: "Churchill gives word that we have found ourselves in an occupied zone. Well, that's how it was literally - Greece is a country occupied by the English. And we respond...." The monologue runs like a recording without pause and concerns both the concrete course of the war itself and the level of global politics and its ideological assessment. My interlocutor takes no notice of the anthropologist's queries; his goal is to present what is most important to him, what everyone should know and what (as one quickly deduces) precisely demarcates his present-day identity.

16 E. Nowicka, Hermes, Odyseusz i greckie powroty do ojczyzny, Kraków 2008; E. Nowicka, Wojna jako element opowieści biograficznej greckich repatriantów z Polski, in: Pamięć zbiorowa jako czynnik integracji i źródło konfliktów, ed. A. Szpociński, Warsaw 2009, p. 73-124. 


\section{LIFE IN POLAND}

Contact with Polish reality is described by my respondents as a shock, but a positive one. Living conditions in Poland are today assessed as very good in the eyes of the Greek interviewees - or even luxurious when compared with those in backward and war torn Greek villages or when compared to the general living standard in postwar Poland. Re-immigrants speak of wonderful conditions in hospitals and sanatoria to which the great majority of the adult and children contingents were sent; they also cite the dedication and devotion of the Polish doctors and nurses as well as the sacrifice that Polish society made on behalf of the Greek newcomers.

At the same time, these narrators note that a serious transformation was inevitably taking place in the customs, habits, and lifestyle of the refugees. Despite preventative actions taken by the oldest generations, this process already began in the 1950s and picked up speed in the 60s and 70s. Life goals, aspirations, and behavior were changing. Becoming more of a source of prestige during their lives in Poland were nicely appointed homes and automobiles, rather than the traditional large Greek family. Greek marriages in Poland yielded fewer children which was facilitated by the careers of the women. Predictable generational differences were also made manifest: young Greeks sometimes escaped from family circles because the ways of thinking and doing of the oldest generation were, for the youth, relicts of the past.

A significant phenomenon of this particular emigration group was the lack of newer immigrants and hence, for some, this milieu became unbearably closed-minded and provincial. This frequently moved the younger generations to reject the patterns of the old country, and to assimilate to the Polish patterns of urban life. The role of the great, multigenerational, and multi-branched Greek family constellation decreased; life forced an increased individualization. Often successful economic and social advances led to a departure from the life values and patterns typical of traditional Greek culture. ${ }^{17}$ Certain changes turned out to be practical or even necessary - e.g., adjusting the spelling of Greek names to the Latin alphabet and to Polish pronunciation. At times this led to even a complete change of first and/or last names, especially if these bore negative or even offensive connotations in the new context. ${ }^{18}$

Inasmuch as Poland was a country of exile for those who had arrived here as adults, ties to the new land formed naturally for those born in this country. This especially evolved as Greeks in Poland became less and less isolated in segregated environments, less and less separated by the ideological hardcore communists from everyday Polish economic conditions. Usually young people of secondary or tertiary education level study began to make friends and entered into closer relations with

${ }^{17}$ M. Wojecki, op. cit.; W. Markiewicz, op. cit.

18 Two female respondents chuckled during a conversation in which one recalled a male friend from a northern Greek village who had to change his surname since Polish teachers could not bring themselves to read it or did, but at risk of inducing thunderous laughter. This young man's Greek last name was Kutas, a Polish synonym for prick in English. 
Poles, managing to extract themselves from the supervision of both their ideological leaders and their parents. The world of these young people began to seem more open, diverse, and multi-dimensional. Among the Poles, these young Greeks met up with clear enemies of communism and of the Polish People's Republic (PRL) with its totalitarian system. In turn, this disintegrated the ideological unity of the worldview and lifestyle transmitted to them by their parents.

However, the first years in exile were a period of permanent mobilization, especially for the young. Constantly being prepared for ostensibly ensuing stages of the partisan war, they were conducting daily drills, learning Greek, and singing military and patriotic songs. The initial period of immigration - whether in Poland or some other Soviet Bloc state - comprised a life under the full control of the Communist Party of Greece. Yet the discipline gradually loosened; more and more people took up life under their own control.

In Poland the refugees from Greece were treated as stateless persons - they did not automatically receive Polish citizenship. In fact, there was never any pressure on their part to gain such passports as they lived with the thought of a return to their homeland in short order: Poland was treated as a momentary episode in their lives. As proof of identity, they presented two documents: that of a resident alien in Poland and that of their permanent residency in Greece. Among their tales of life in Poland there are memories of holidays which were celebrated with a roasted lamb, a sense of deep solidarity with Greeks far and wide, and the invariable toast to Next year in Greece!

Poland - like the other states in which they were settled - was not a destination point for anybody, nor did it become one in the course of a dozen or so years, even if the country was viewed in a very positive light. None of the Greek citizens planned to remain in Poland despite the exceptionally advantageous conditions which had been created for a people forced to emigrate and forced to settle in Poland (or elsewhere). Different was the situation in the USSR wherein the Greeks were designated as the builders of a modern Tashkent and lived under extremely difficult conditions. ${ }^{19}$

\section{GREECE! GREECE! DREAMING OF RETURN}

Regardless of the living conditions, a return to the homeland was absolutely the imagined life goal to which all other decisions (such as getting married) had to be adapted. Amidst the peons of praise for Poland and the Poles which were declared to this Polish anthropologist, a reticent theme is glimpsed: a sense of being a stranger in a strange land and the longing for the home country so fondly remembered - even if only fragmentarily or known only through the tales of the older generations. Nonetheless, a return for the majority of the emigrants would not be possible. Some annually filed for

19 E. Voutira, Ethnic Greeks from the Former Soviet Union as 'Privileged Return Migrants, „Espace populations societies", 2004, no 3, p. 533-544; D. Kalamvrezos, Greeks of the Former USSR since 1991, "Journal of the Hellenic Diaspora", 2005, no 2, p. 29-58. 
official permission to come back to Greece and then, systematically, for well over a decade, received an annual refusal from the Greek government. Any link with the communist partisans - even if an unproven suggestion, even if it regarded a child disqualified the filing party from the right to return.

\section{RETURN - A TOUGH REALITY}

Not only a brutal extraction from one's home environs, from a natural and cultural landscape, but also a return thereto was associated with numerous material and psychological difficulties. This was not the same Greece and the returnees were not the same people: the house had changed, and so had the household members. After years of traveling in foreign lands, Odysseus recognized his homeland with great difficulty and his compatriots no longer saw him as one of their own.

After the Second World War, Greece was devastated economically and demographically; the civil war exponentially increased that devastation. Assistance coming from the West which was, in other countries, allocated to the reconstruction of infrastructure, was utilized in Greece to deal with the internal enemy once and for all. ${ }^{20}$ Greece became a country wholly dependent upon the USA. Because it was the sole noncommunist country in the Balkans, defending and securing it from communism became the fundamental aim of successive governments which only to a small degree took care of rebuilding the country and reforming it democratically.

In fact, political circumstances immediately after the war did facilitate democratization, but already by 1952 ruthless right-wing regimes began to apply martial law tactics even if such a formal designation was lifted in February 1950. A political vetting of each and every individual was undertaken, regardless of whether he or she was applying for a government position, a passport, or simply a driver's license.

Nevertheless, April 1952 witnessed the abolition of the death penalty, convictions were annulled, and sentences in political affairs were reduced. The political atmosphere in Greece was decisively eased and taken in the direction of a national reconciliation. As of 1953 a period of economic stability began, small businesses developed, and trust in the Greek drachma was strengthened. With the Greek Civil War over, an exodus ensued from the ruined villages to the cities; very quickly about $10 \%$ of the entire general population underwent a rapid urbanization. In 1951, urban residents constituted $38 \%$ of the country's population; by 1971 they constituted $53 \%$. Athens grew abruptly, but so, too, did a massive economic emigration abroad: between 1951-1980, $12 \%$ of the entire population of Greece left the country.

After 1956, a portion of the Greeks deported during and after the civil war returned home. These were, however, a small group of individuals who, as a result of unforeseen circumstances or against their will, found themselves in the wave of refugees. Some had been captured prisoners of war who had fought for the royal army,

${ }^{20}$ R. Clogg, op. cit. 
but happened to be held in communist partisan quarters; others were blameless civilians. Another period in which a segment of the Greeks came home was in 1964-1965 when the rightwing regime briefly thawed.

Moreover, the refugees in Poland included those who self-identified as Macedonian, not Greek. Therefore - as a matter of necessity, because without renouncing their "Macedonianness" they were banned from Greece - they chose a "return" to Yugoslavia, to the Macedonian Republic of that country. After the fall of the Soviet Bloc, in the 1990s, most of the remaining Macedonian refugees finally accepted Polish citizenship and, on this basis, were granted permission to enter Greek territory.

That said, the majority of Greeks deported to various eastern bloc states during the civil war returned to their homeland only after 1974 at which point the political orientation of the Greek government had shifted. An honorable return is one which necessitates no special or additional conditions - and precisely this type of comeback was expected and requested by the refugees. They also demanded a full amnesty for the Macedonians, the Slavic speaking Greeks.

Until 1974 the Greek regime did not permit entrance even for a temporary stay or family visit. A member of the Greek diaspora who applied for the right of return at an embassy or consulate of Greece was required to complete a very long and detailed questionnaire regarding his or her attitudes or affiliations with the 1946-1949 political organizations and any participation in battle. Further mandated was severance of any ties with the Communist Party of Greece, any political engagement, and any communistic views. As of 1975, the situation changed and the questionnaire included only ten points, much less probing or troublesome for the applicant.

Now permission to return was granted not only for those who simply found themselves among the expelled, but even for those who had been active partisans and their progeny. ${ }^{21} \mathrm{M}$. Wojecki estimates that the number of Greeks in Poland had dropped by 1982 to approximately $6,000 .^{22}$

\section{UPON RETURN TO THE HOMELAND}

The returns, in fact, generally began with semi-touristic, reconnaissance visits. Considering that the end of the 1970s and beginning of the 1980s was a period of great economic troubles and goods deficiencies in Poland, the humiliating daily battles to satisfy the most basic of needs as well as the hopelessly grey life of that closed society encouraged and pushed the Polish Greeks towards the idea of permanent return. This had been a long unfulfilled dream, but the reality upon resettlement turned out to be less rosy than imagined. My respondents spoke of how they suffered and continue to suffer after returning to the homeland - to the more local and private as well as the

\footnotetext{
21 E. Voutira, op. cit.; D. Kalamvrezos, op. cit.

22 M. Wojecki, op. cit.
} 
more national and public - for which they had yearned so long. Difficulties appeared in all spheres of life.

Those migrating back sometimes spoke Greek poorly because they had completed elementary and secondary (and often tertiary) education in Polish. Moreover, many of the parents of children placed in orphanages had been illiterate and hence the latter only knew the Greek language at the level of their unschooled parents. Neither the competencies of the teaching personnel, nor the number of weekly hours devoted to Greek could provide a deep familiarity and fluency in the language of their forefathers. Additionally, the language which they had learned from their parents was often a local, rural dialect which in Greece of the 70s, 80s and later could only evoke indulgence or even contempt. Compounding the problem was the number of evacuated who were Macedonians speaking a Slavic language or Wallachians speaking a Romance language: their Greek was accented by the influence of the local ethnic tongue.

Additionally, the government of Greece was not facilitating re-adaptation for returning members of the fold. Among other things, concrete legal moves made earlier now blocked the path back to property inherited from their forefathers. Land ownership had generally been transferred officially in gratitude for service to the country, or had been divided and distributed among family members who had stayed behind (and for whom the absence of others was convenient). A return back to the same locality sometimes reignited old family conflicts. I discovered the situations in which, to this day, siblings maintain no contact with each other in Greece, precisely due to property disputes. Overall, many a person spoke of his or her initial re-contact with Greece in terms of the material difficulties which had to be faced upon return.

Among other things, the villages in which parents had lived before the war had been destroyed; often there were no longer any old homes. More than a few villages had been wholly burned to the ground - sometimes all that remained were stone skeletons signifying the traditional Macedonian building style. It was also often impossible to return to one's old work style - not only farming was less of an option, so was shepherding without a herd. Another hindrance to a return home was that younger Greeks who had been raised in cities and had achieved an education did not much want to return to the lifestyle of their fathers - even if the houses, fields, and sheep were still in possession. More symbolically, the names of the expatriated had occasionally been struck from local documents and records, meaning de facto that they were seen as dead or as not ever having existed.

Finding employment was not easy despite having a good secondary or tertiary education attained in Poland or other diaspora settlement. In fact, the repatriates were, to a great degree, more educated than their relatives and neighbors who had stayed behind. Recognition of diplomas was not a simple matter; at least in the beginning, this precluded undertaking a job in one's field and/or at a suitably high level. That said, these are, more or less, problems which immigrants face in countries around the world. Yet a lack of connections and beneficial relations in Greek circles (upon which most employment in Greece is based) hindered the making of a professional career, 
or sometimes even hampered biological and physical survival. Practically speaking, it is nearly impossible to take care of any civil, bureaucratic matter without so-called "friends" or other contacts; nepotism and familial clanships are obvious upon a closer look. My respondents, re-immigrants from Poland, complained about interpersonal relations which were described as unfriendly or antipathetic though undoubtedly also rooted in the long-term absence and disconnection.

Today repatriates admit that their return to Greece was not embarked upon with full awareness:

They had no idea. I look back at how we left Poland - after all, as a translator, I had even participated in talks between representatives of the Polish and Greek governments. It was [the Greeks] who had promised that each person with, say, a university education would come back to Greece and get a job from the start, that the Greek government guarantees them work. Work and a place to live. And this is how it ended up: nothing, zero. Nobody who came got anything, but ended up on the streets or had someone with whom they could stay or scrimp along like we did. It was hard at the beginning.

It should be noted that even now the appearance of the Thessaloniki apartments of married re-immigrants is very modest, if not to say penurious. Only a few have been able to regain the status they enjoyed in Poland, or could have today when considering their mastered qualifications. None of the research subjects has returned precisely to the same work and to the same conditions of life as before the exile. Nearly no one returned to their field farming and animal husbandry, even if some do reside in villages, usually even their home villages. There they go to the cemeteries to visit the graves of their parents and grandparents as well as their brothers and sisters who lost their lives during the civil war, or who died in exile in one of the Soviet Bloc countries, even in Uzbekistan.

The subject of the civil war has basically disappeared from the media, but the oldest Greek repatriates continue to be treated with distrust and disregard. The average Greek citizen, according to my interviewees, lives for today. Nevertheless, perhaps because no lustration or vetting was ever completed in Greece, the issues of a "political sin" and "forgiveness" do occasionally resurface. The Greek Civil War and of the people who, as a consequence, were cast out of their homeland are uncomfortable and troublesome topics. Rarely opened for discussion, this issue is flung back to distant history.

The Greek citizens of the eldest generation returned to a completely different country - one that had been urbanized and significantly transformed after decades of industrialization. Old homes ruined by the war or by time were replaced by much more modern buildings with all imaginable comforts. The younger generations who had never experienced Greece faced one different from the country known from the mythologized tales of parents and grandparents. Over the course of the decades which had passed while they were exiled in Poland, life in Greece had changed and so had the people who were returning.

A side effect of the above are problems with identity. More than once I heard in conversations: "We are different." My respondents, repatriated from Poland, have of- 
ten emphasized that they feel uncomfortable in Greece; different customs and lifestyles, interpersonal attitudes and relationships, and a level of personal hygiene perceived as lower are among the things that dismay. Antipathy is even aroused by the culinary habits of the Greeks: "A heap of meat, usually roasted. I call these barbarian dishes because I like everything to be placed on my plate, and for it to be a normal portion. These are customs from which a person cannot dissociate, from which a person cannot free himself." This same individual who spent over three decades in Poland generalizes further: "I have more Polish customs in me than Greek - in my behavior, in everything." Due to the differences in character between Poles and Greeks it has been difficult, as my respondents have asserted, to adjust and adapt anew to life in Greece; the re-immigrants have adopted too much from the Poles even on the level of personality traits. ${ }^{23}$

The land of their forefathers, often recalled from childhood as an idyllic past, had become a foreign country - a strange place requiring adaptation and change. Many mixed marriages made in Poland, fell apart in Greece. Some of the Polish spouses fled back to Poland; this was especially true of the Polish women who were accustomed to more equal status and could not bear their lower position in the Greek family. Likewise, Greek women raised in Poland but who married Greeks in the homeland after returning also found it hard to accept family relationships in Greece - this, too, often led to divorces.

Irritating, from the perspective of the repatriates, has been less education or less awareness about the world at large (and about Poland, in particular) among the average Greeks. Today's everyman in Greece knows very little - in fact, practically nothing - about Poland, and what passes for "knowledge" is sometimes deeply mistaken. If there are any images of Poland and Poles they are based on stereotypes shaped in the times of the rightwing Greek regimes and the communist Polish ones. Furthermore, contemporary partisan conflicts and the polarization of political views in Greek society support depictions of Poland as a postcommunist (or fundamentally still communist) country. It is seen as being just like any other country of the former Soviet Bloc, identical to the Czechs, Slovaks or even the Soviet Union. Poland is perceived as a post-Soviet country, more backwards and insignificant than is actually the case. Little is known about Polish history, let alone about the transformations which Poland has accomplished.

When present-day repatriates left Greece those many decades ago, they knew the same about Poland and the other destination countries as those who remained in Greece. But naturally it is a different situation today: knowledge about Poland is incomparably greater among the returnees. One man who had an academic career in Poland and took up a similar position in Greece, spoke with reluctance and irony about the ignorance of the average Greek: "A colleague of mine came back from

${ }^{23}$ E. Nowicka, Identity of Greek repatriates from Poland: Return home or new migration?, in: Homecoming: An Anthropology of Return Migrations, ed. E. Nowicka, H. Firouzbakhch, Kraków 2008, p. 59-78. 
Poland; after a conference in Poland, there was one in Prague, too. When he came back, we started to talk: 'You know what, I had no idea that Poland is a country standing on such a high civilizational and social level!"” My respondent had a retort to this reaction: "What were you thinking - that people live only here in Greece and in the West and over there they are just waiting in the dark for some help to come?"

The above-referenced man was, to some degree, identifying with Poland which had provided him (as he states) with an education and deep training and insight in his field. He recalled the negative effects, on the one hand, of the dominance of communist Greek leaders on the emigrants, and, on the other, of assimilatory contacts with Polish youth. The latter he now saw as "terrible" - the shedding of Greek culture and identity is not described as desirable. Presently, after years spent in Poland and then in Greece, the re-immigrants sense their being "alien" vis-à-vis both Poland which they consciously chose to leave, and Greece where they were not greeted with open arms: they feel strange both here and there. Among them are those with a dual identity as well as those with a disrupted or blurred identity - an aching feeling of being uprooted and no longer able to replant oneself anywhere.

\section{CONCLUSIONS}

Every emigration bears hidden possibilities or sometimes even forebears re-immigration, repatriation, and return migrations. In the case of a forced migration, the prognostication escalates with exceptional intensity. Expulsion - always, without exception - evokes a nostalgia for one's motherland, for one's heimat or private homeland, for familiar landscapes, and for familiar social milieus. It arouses (at least in the first generation of emigrants) a longing to return to the mythologized and ideologized home country, to return home - and this becomes a goal towards which one works. Involuntary migration is exceptionally painful: it is inevitably associated with loss of a feeling of safety and security and loss of control over one's own destiny.

Nevertheless, in a psychological sense, it is an easier migration because blame for all the (often traumatic) sufferings which are experienced as a result rests on others: some strangers, enemies, or external forces. The burden for any sadness, tragedy or failure which is a consequence of the forced migration need not fall on the individual - as is necessary in cases of voluntary migration wherein letdowns or disappointments are ultimately assigned to one's own incapabilities or bad decisions.

That said, the forced migration also brings a certain immanent dramatism whose negative consequences are irreparable. Even a return - which, in principle, should reinstate balance -does not resolve the problems instigated by the initial move; quite the contrary, it produces new ones. The fate of the Greek citizens (regardless whether of a Greek or non-Greek ethnic identity) of whose involuntary emigration and voluntary immigration I write is a case study which perfectly illustrates the traumas of the first as well as the later stages. 
The history of the Greek refugees and returnees presented above illustrate the irreversible and irreparable social and psychological shocks induced by the forced migration. Any and all compulsory resettlement of a population leads to the severance of bonds with the homeland, with the hometown, and with the culture of one's home country. This, in turn, provokes subsequent conflicts and problems with identity which continue to trouble those who physically return to their birthplace. Such a comeback does not restore balance; it does not abate the quandaries instigated by the initial displacement. That uprooting persists in the memories as well as in the daily lives of the return migrants - and it continues to trigger still further problems.

\section{REFERENCES}

Clogg, R., A Concise History of Greece, Cambridge 1992.

Danforth, L.M., We Crossed a Lot of Borders. Refugee Children of the Greek Civil War", "Diaspora: A Journal of Transnational Studies", 2003, no 2, p. 169-209.

Gawęcki, M., Kazachstańscy Polacy, Warsaw 1996.

Główny Urząd Statystyczny (GUS), Ludność wedtug deklaracji narodowościowej oraz posiadania obywatelstwa polskiego w $2002 \mathrm{r}$., http://stat.gov.pl/spisy-powszechne/narodowe-spisy-powszechne/ narodowy-spis-powszechny-2002/wyniki-narodowego-spisu-powszechnego-2002-narodowoscioraz-jezyka/ [Access: 06.12.2016].

Hut, P., Warunki życia i proces adaptacji repatriantów w Polsce w latach 1992-2002, Warsaw 2002.

Kalamvrezos, D., Greeks of the Former USSR Since 1991, "Journal of the Hellenic Diaspora", 2005, no 2, p. 29-58.

Marantzidis, N., The Greek Civil War (1944-1949) and the opening of archives in post-communist Europe, in: The Polish People's Republic and the Greek Civil War, ed. M. Semczyszyn, Szczecin, 2016.

Marantzidis, N., The Greek Civil War (1944-1949) and the International Communist System, "Journal of Cold War Studies", 2013, no 15(4), p. 25-54.

Markiewicz, W., Przeobrażenia świadomości narodowej reemigrantów polskich z Francji, Poznań 1960.

Nowicka, E., Migracje powrotne jako przedmiot badań, „Przegląd Polonijny”, 2007, no 2, p. 75-92.

Nowicka, E., Hermes, Odyseusz i greckie powroty do ojczyzny, Kraków 2008.

Nowicka, E., Identity of Greek repatriates from Poland: Return home or new migration?, in: Homecoming: An Anthropology of Return Migrations, ed. E. Nowicka, H. Firouzbakhch, Kraków 2008, p. 59-78.

Nowicka, E., Wojna jako element opowieści biograficznej greckich repatriantów z Polski, in: Pamięć zbiorowa jako czynnik integracji i źródto konfliktów, ed. A. Szpociński, Warsaw 2009, p. 73-124.

Stawowy-Kawka, I., Historia Macedonii, Wrocław 2000.

Szymczyszyn, M., The Greek Civil War (1944-1949) - outline", in: The Polish People's Republic and the Greek Civil War, ed. M. Szymczyszyn, Szczecin 2016, pp. 23-43.

Boeschoten van, R., The impossible return: coping with separation and the reconstruction of memory in the wake of the Civil War, in: After the War was Over: Reconstructing the Family, Nation and State in Greece, 1943-1960, ed. M. Mazower, Princeton 2000, p. 122-141.

Voutira, E. (2004). Ethnic Greeks from the Former Soviet Union as 'Privileged Return Migrants', „Espace populations societies", 2004, no 3, p. 533-544.

Wojecki, M., Uchodźcy polityczni z Grecji w Polsce 1948-1975, Jelenia Góra 1989. 